\title{
The relationship between the thyroid gland and body at different gestational age of developing human foetuses
}

\author{
Rajeev Mukhia', Bhawani Prasad Powar ${ }^{2}$ \\ ${ }^{1}$ Lecturer, ${ }^{2}$ Professor, Department of Anatomy, Manipal College of Medical Sciences, Pokhara, Nepal
}

Background: Thyroid gland is one of the organs of interest for researchers since a long time. Though, detailed study about adult thyroid gland is there in the literature but thyroid gland at different stages in the foetal period is far less available. Aims and Objective: To find out the morphological and morphometric features on the development of foetal thyroid gland in relation with different gestational weeks. Materials and Methods: The study was carried in the Department of Anatomy, Manipal College of Medical Sciences, Pokhara, Nepal, on 40 human foetuses of known gestational age. The midline dissection of the neck was done to expose the thyroid gland. The shape and measurements like length, breadth and thickness of both lobe of the gland were noted. Results: The mean values of all parameters by gestational age were calculated. In the present study, the weight of foetuses showed gradual increase from $10^{\text {th }}$ week to $38^{\text {th }}$ weeks of gestation. In the normally developing foetuses the thyroid gland dimension and its weight also increases with increase gestational age. Conclusion: There was no more difference between the dimension of right and left lobe of thyroid gland. The study provides morphological and morphometric knowledge on the development of foetal thyroid gland from $10^{\text {th }}$ week to $38^{\text {th }}$ weeks of gestation. The knowledge of thyroid gland weight and dimension and body weight in relation to the gestational age might be helpful to judge the thyroid structure in preterm babies.

Key words: Human foetuses; Thyroid gland; Location; Dimensions; Development
Access this article online

Website:

http://nepjol.info/index.php/AJMS DOI: 10.3126/ajms.v9i6.20868 E-ISSN: 2091-0576 P-ISSN: 2467-9100

\section{INTRODUCTION}

In human beings, the thyroid gland is one of the largest and earliest endocrine organs to develop and differentiate. It has an important hormonal role in embryonic development. ${ }^{1}$ The thyroid gland, brownish-red and highly vascular endocrine gland, is placed anteriorly in the lower neck region. It extends from $5^{\text {th }}$ cervical to the $1^{\text {st }}$ thoracic vertebrae. It consists of right and left lobes connected by a narrow isthmus. It usually weight about 25 gram but this varies. The gland is slightly heavier in females as compare to male and it enlarges during the time of menstruation and pregnancy. ${ }^{2}$ Estimation of the size of the thyroid gland is clinically important in the evaluation and management of thyroid disorders and can be achieved non-invasively by means of diagnostic ultrasound. Mean thyroid volume increases with age. ${ }^{3}$ The lobes of the thyroid gland are approximately conical. Each lobe is about $5 \mathrm{~cm}$ long, its greatest transverse and antero-posterior extents being $3 \mathrm{~cm}$ and $2 \mathrm{~cm}$, respectively. The postero-medial aspects of the lobes are attached to the side of the cricoid cartilage of larynx by a lateral thyroid ligament (Berry's ligament). The isthmus of the gland connects the lower parts of the two lobes, and occasionally it may be absent. It measures about $1.25 \mathrm{~cm}$ transversely and vertically, and is usually anterior to the second and third tracheal cartilages. A conical pyramidal lobe of the gland often ascends towards the hyoid bone from the isthmus. A fibrous or fibromuscular band, the levator of the thyroid gland, musculus levator glandulae thyroideae, sometimes descends from the body of the hyoid to the isthmus or pyramidal lobe. ${ }^{4}$ Ectopic thyroid gland is rare but may be found laterally in the neck or 
around the thyroglossal duct or, as well as in distant places such as the tongue (lingual thyroid), mediastinum and the subdiaphragmatic organs. The most frequent location of ectopic thyroid gland tissue is at the base of the tongue, in particular at the region of the foramen caecum. ${ }^{5}$ Under the influence of fibroblast growth factors, the thyroid gland is the first endocrine gland to develop in the embryo. The gland begins to form about twenty four days after the fertilization from the endodermal thickening in the floor of the developing pharynx. This endodermal thickening soon forms a small outpouching, the thyroid primordium. As the developing embryo and tongue grow, the developing thyroid gland descends in the neck region, passing ventral to the developing hyoid bone and laryngeal cartilages. For a short time, the gland is connected to the tongue by a narrow tube, the thyroglossal duct. At first, the thyroid primordium is hollow, but it soon becomes a solid mass of cells. It divides into right and left lobes that are connected by the isthmus of thyroid gland, which lies anterior to the developing second and third tracheal rings. At 7 weeks, the thyroid gland has assumed its definitive shape and is usually located in its final site in the neck. ${ }^{6}$

Since, the growth of thyroid gland in human foetuses with respect to the gestational weeks in the previous literatures were found to be inadequate, hence the present study was done to study the morphological and morphometric features on the development of foetal thyroid gland in different gestational weeks. Though, detailed of the adult thyroid gland is available the studies of the foetal thyroid gland have still a large scope for researchers.

\section{MATERIALS AND METHODS}

The present study was carried out on forty normal human foetuses, aged between $10^{\text {th }}$ to $38^{\text {th }}$ gestational weeks. The normal foetuses were obtained from the Department of Obstetrics and Gynaecology, Manipal College of Medical Sciences Teaching Hospital, Fulbari, Pokhara. After ethical review and permission from the concerned authorities of the Institute, the foetuses were collected in 10\% formalin for carrying the study. The foetuses included the spontaneous abortion and still born foetuses. Cases with any anomaly or pathology were not included in the study. The age of foetuses was calculated from the crown rump length (CRL), crown heel length (CHL) and obstetrical history. The weight of the foetuses was measured in grams on digital weighing machine. The midline dissection of the neck was done to expose the thyroid gland. The dissection was done according to the "Cunningham's manual of practical anatomy $15^{\text {th }}$ edition". " The shape of the gland was noted. The weight of the thyroid gland was measured in grams on digital weighing machine. Dimensions like length, breadth and thickness of foetal thyroid gland were recorded by vernier calliper. All the data were represented as mean then analyzed with MS Excel 2007 software and represented graphically.

\section{RESULTS}

The present study was carried out in the Department of Anatomy, Manipal College of Medical Sciences, Pokhara, from August 2017 to July 2018. Total forty human foetuses ranging from $10^{\text {th }}$ to $38^{\text {th }}$ weeks were studied. The mean values of all parameters by gestational age were calculated. In the present study, the weight of foetuses showed gradual increase from $10^{\text {th }}$ week of gestation. The thyroid gland was butterfly shaped and located anteriorly in the lower neck region and related with $2^{\text {nd }}$ to $6^{\text {th }}$ tracheal rings in majority of foetuses. The measurement of the foetal weight is shown in figure 1. The dissection of foetuses is shown in figure 2. The measurement of the weight of foetal thyroid gland is shown in figure 3 . The measurement of the dimension of foetal thyroid gland is shown in figure 4 .

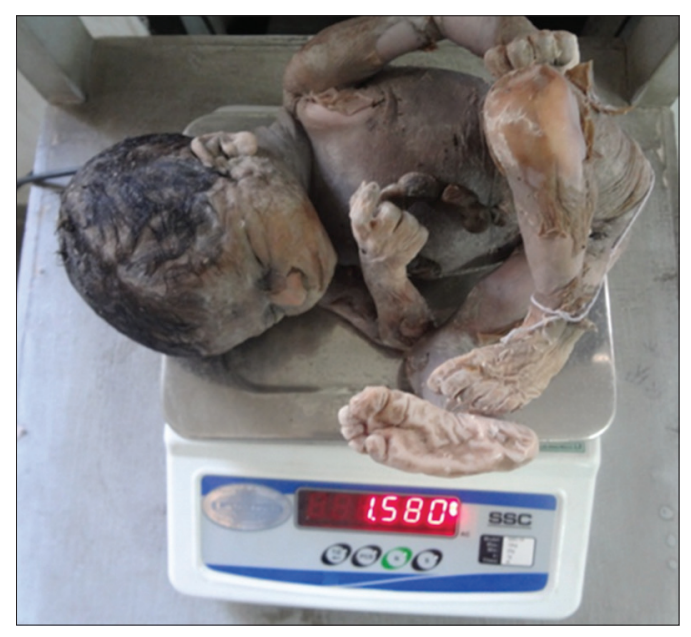

Figure 1: Calibrating weight of foetus

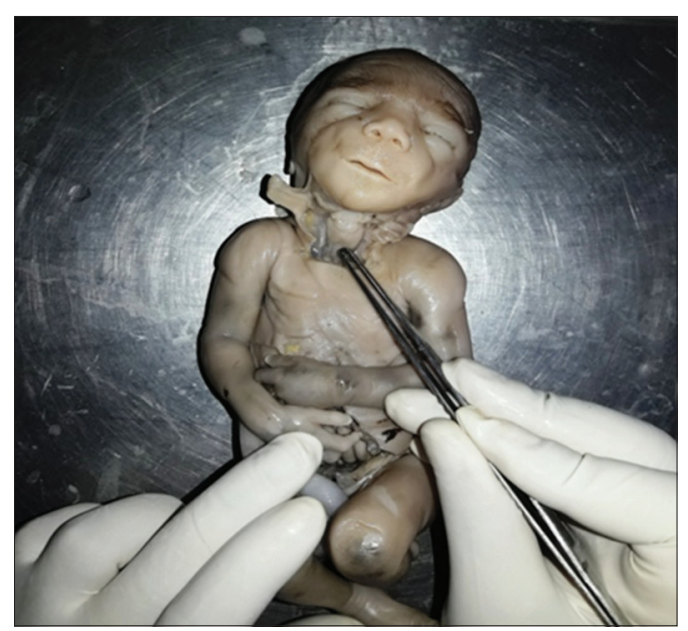

Figure 2: Dissection of thyroid gland 
The results of mean body weight, weight of thyroid gland and ratio of thyroid gland and foetal weight is shown in table 1 , figure 5 and 6 . The results of mean of dimensions (length, breadth and thickness) of thyroid gland are shown in table 2 and figure 7.

\section{DISCUSSION}

Increase in organ weight as well as foetal weight is a good indicator of foetal growth in general. Rate of weight gain

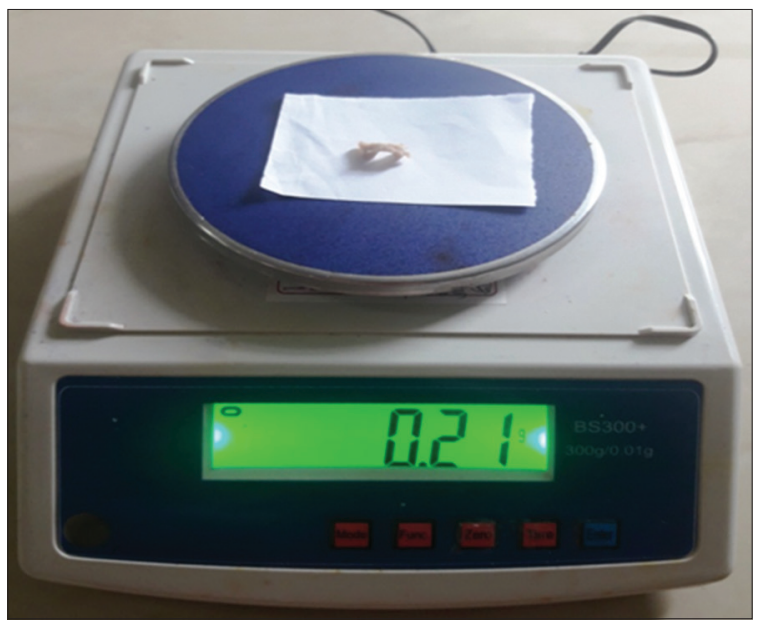

Figure 3: Measuring weight of thyroid gland

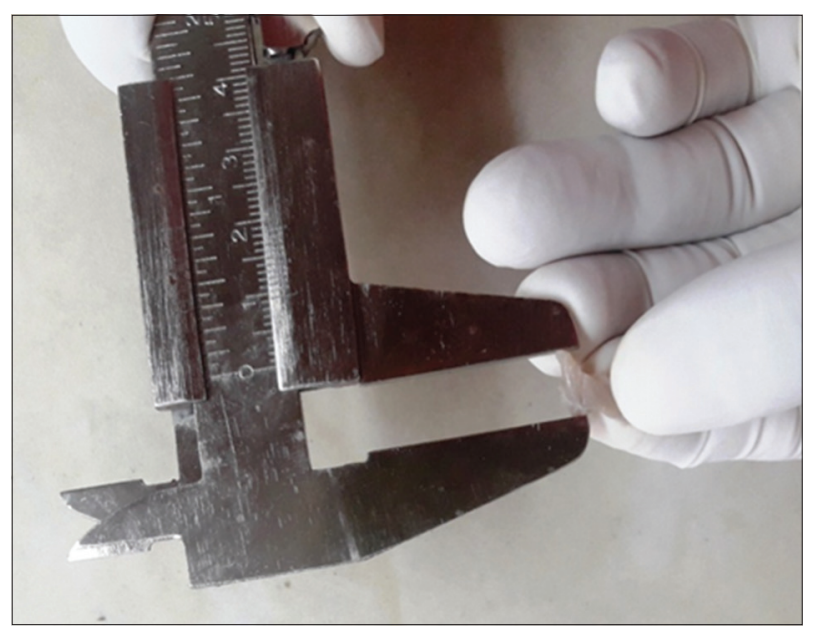

Figure 4: Measuring dimension of thyroid gland during late gestational age differs considerably with early gestational age. In the present study the weight of foetuses showed gradual increase from $10^{\text {th }}$ week to $38^{\text {th }}$ weeks of

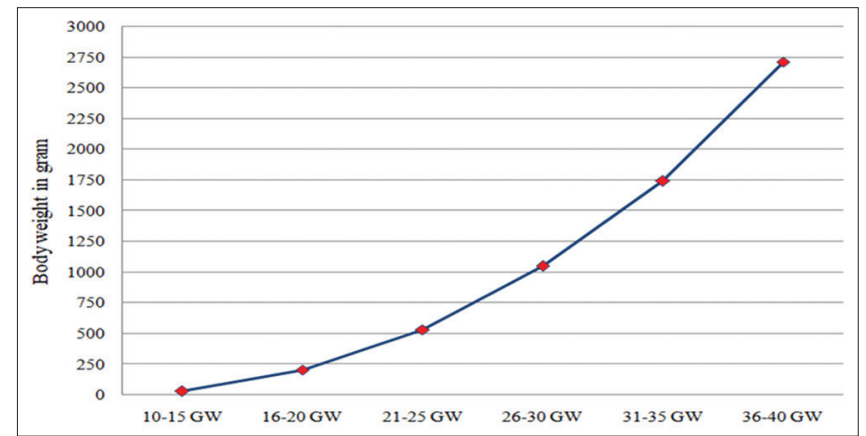

Figure 5: Linear graph showing relationship between body weights against gestational weeks

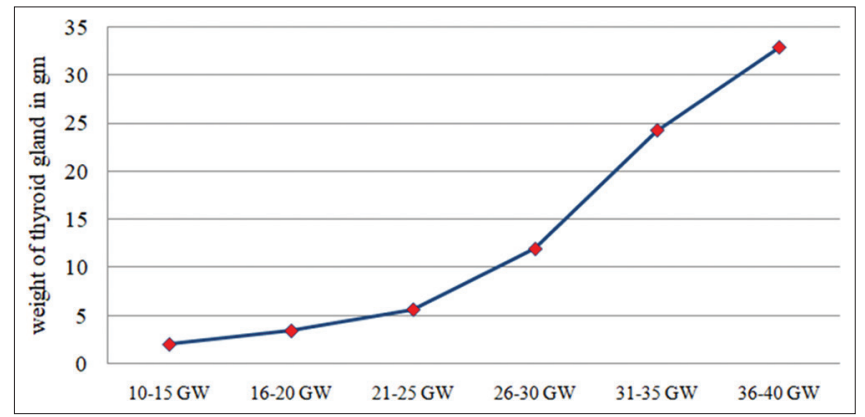

Figure 6: Linear graph showing relationship between thyroid gland weights against gestational weeks

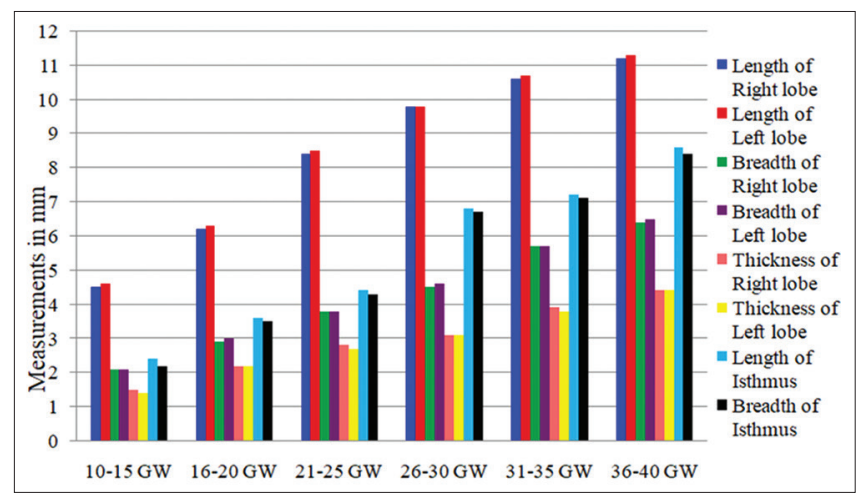

Figure 7: Showing mean dimensions (length, breadth and thickness) of thyroid gland in $\mathrm{mm}$ against gestational weeks (GW)

\begin{tabular}{|c|c|c|c|c|c|}
\hline Groups & $\begin{array}{l}\text { Gestational } \\
\text { weeks (GW) }\end{array}$ & $\begin{array}{l}\text { Number of } \\
\text { foetuses }\end{array}$ & $\begin{array}{l}\text { Body weight } \\
\text { in gm }\end{array}$ & $\begin{array}{l}\text { Weight of thyroid gland } \\
\text { in gm }\end{array}$ & $\begin{array}{c}\text { Ratio of gland \& body } \\
\text { weight }\end{array}$ \\
\hline Group I & $10-15$ & 7 & 30 & 2.0 & 0.06 \\
\hline Group II & $16-20$ & 8 & 205 & 3.4 & 0.01 \\
\hline Group III & $21-25$ & 7 & 532 & 5.6 & 0.01 \\
\hline Group IV & $26-30$ & 8 & 1048 & 11.9 & 0.01 \\
\hline Group V & $31-35$ & 4 & 1741 & 24.2 & 0.01 \\
\hline Group VI & $36-40$ & 6 & 2712 & 32.8 & 0.01 \\
\hline
\end{tabular}




\begin{tabular}{|c|c|c|c|c|c|c|c|c|c|}
\hline \multirow{2}{*}{$\begin{array}{l}\text { Gestational } \\
\text { weeks (GW) }\end{array}$} & \multirow[t]{2}{*}{ Number of foetuses } & \multicolumn{2}{|c|}{ Length in $\mathrm{mm}$} & \multicolumn{2}{|c|}{ Breadth in mm } & \multicolumn{2}{|c|}{ Thickness in $\mathrm{mm}$} & \multicolumn{2}{|c|}{ Isthmus } \\
\hline & & $\begin{array}{l}\text { Right } \\
\text { lobe }\end{array}$ & $\begin{array}{l}\text { Left } \\
\text { lobe }\end{array}$ & $\begin{array}{l}\text { Right } \\
\text { lobe }\end{array}$ & $\begin{array}{l}\text { Left } \\
\text { lobe }\end{array}$ & $\begin{array}{l}\text { Right } \\
\text { lobe }\end{array}$ & $\begin{array}{l}\text { Left } \\
\text { lobe }\end{array}$ & $\begin{array}{l}\text { Length in } \\
\mathrm{mm}\end{array}$ & $\begin{array}{l}\text { Breadth in } \\
\mathrm{mm}\end{array}$ \\
\hline $10-15$ & 7 & 4.5 & 4.6 & 2.1 & 2.1 & 1.5 & 1.4 & 2.4 & 2.2 \\
\hline $16-20$ & 8 & 6.2 & 6.3 & 2.9 & 3.0 & 2.2 & 2.2 & 3.6 & 3.5 \\
\hline $21-25$ & 7 & 8.4 & 8.5 & 3.8 & 3.8 & 2.8 & 2.7 & 4.4 & 4.3 \\
\hline $26-30$ & 8 & 9.8 & 9.8 & 4.5 & 4.6 & 3.1 & 3.1 & 6.8 & 6.7 \\
\hline $31-35$ & 4 & 10.6 & 10.7 & 5.7 & 5.7 & 3.9 & 3.8 & 7.2 & 7.1 \\
\hline $36-40$ & 6 & 11.2 & 11.3 & 6.4 & 6.5 & 4.4 & 4.4 & 8.6 & 8.4 \\
\hline
\end{tabular}

gestation. Numerous previous studies dealing with the development of the human thyroid gland in foetal period mainly contain qualitative descriptions processes and report changes in the weight of the gland. In the present study, the thyroid gland weight between $10^{\text {th }}$ to $38^{\text {th }}$ weeks of gestation was found and the mean was slight lower than in the studies done by Shepard et al. (1964). ${ }^{8}$ The results of the present study confirm the earlier findings of Shepard et al. (1964) with relation to the weight of the foetal thyroid gland to the body weight. However, in their studies the relative thyroid gland weight increased up to $80 \mathrm{~mm}$ CRL of development and there after remained constant with the mean $0.0458 \%$ of body weight. ${ }^{8}$ The foetal thyroid gland weight is also comparable to the values calculated from Jackson's (1909) data except for some findings which may be deviated due to difference in sample size of study, genetic and environmental factors which may affects the foetal and thyroid gland development.9 In the present study, it was observed that the thyroid gland was butterfly shaped in majority of foetuses except few which was irregular shape. Harjeet et al. (2004) observed different shapes of isthmus such as horse-shoe shaped, irregular shape and glands with separate lobes. ${ }^{10}$ The absence of isthmus in few specimens was noted by Marshall et al. (1895) studies. ${ }^{11}$ The isthmus of thyroid gland was also observed absent in the studies done by Lokanadham and Devi (2011) in few specimens. ${ }^{12}$ This agenesis may be due to an anomaly of embryological development. The knowledge of the absence of isthmus is significant for surgeons when performing thyroidectomy as it causes difficulty in identifying vessels and hence leading to major complications. ${ }^{13}$ However, in the present study the isthmus was present in all the specimens. In the anatomical study done by Cicekcibasi et al. (2007) the dimensions of the foetal thyroid gland, and in the previous radiological studies done by Bernardes et al.(2008), Ranzini et al. (2001), and Achiron et al. (1998) determined the transverse width of the fetal thyroid. ${ }^{14-17}$ These studies suggested that the dimensions and the transverse width of the foetal thyroid gland increased with increase in the gestational age. In the present study we also observed that the dimensions of the foetal thyroid gland increased as gestational age increased but there were no more difference between the dimensions of right and left lobe. In Moore KL (2006) studies incidence of $80 \%$ of developmental anomalies showed broader right and left lobes. ${ }^{18}$

\section{CONCLUSION}

The measurements of the thyroid gland and body weight were determined from $10^{\text {th }}$ to $38^{\text {th }}$ gestational ages in the present study. The average weight of thyroid gland at $10^{\text {th }}$ to $15^{\text {th }}$ week and $36^{\text {th }}$ to $40^{\text {th }}$ week was $2 \mathrm{gm}$ and $32.8 \mathrm{gm}$ respectively. The relative ratio between thyroid gland weight and body weight at $10^{\text {th }}$ to $15^{\text {th }}$ week and $36^{\text {th }}$ to $40^{\text {th }}$ week are 0.06 and 0.01 respectively. In the normally developing foetuses the thyroid gland weight and dimension increases with advancing gestational age but there was no more difference between the dimension of right and left lobe of thyroid gland. The knowledge of thyroid gland weight and its dimension and body weight in relation to the gestational week might be helpful to judge the thyroid structure in preterm babies.

\section{Acknowledgements}

The author expresses special thanks to all the faculties and non-teaching staff members of Anatomy Department and Obstetrics and Gynaecology Department, MCOMS, Pokhara for their guide and support.

\section{REFERENCES}

1. Braun $E$, Windisch $G$, Wolf $G$, Hausleitner $L$ and Anderhuber $F$. The pyramidal lobe: Clinical anatomy and its importance in thyroid surgery. Surg and Radiol Anat 2007; 29 (1): 21-27.

2. Standring S, Borley NR and Gray H. Gray's anatomy: the anatomical basis of clinical practice. $41^{\text {st }}$ ed. Edinburgh: Churchill Livingstone/Elsevier, 2016, 470-474.

3. Chanoine JP, Toppet V, Lagasse R Spehl M and Delange F. Determination of thyroid volume by ultrasound from the neonatal period to late adolescence. Eur J Pediatr 1991; 150:395-399.

4. Mohebati A and Shaha AR. Anatomy of thyroid and parathyroid glands and neurovascular relations. Clin Anat 2012; 25:19-31.

5. Noussios G, Anagnostis P, Goulis DG, Lappas D and Natsis K. Ectopic thyroid tissue: anatomical, clinical, and surgical implications of a rare entity. Eur J Endocrinol 2011; 165:375-382. 
6. Keith L Moore. The Developing Human Clinically Oriented Embryology: $10^{\text {th }}$ ed. Philadelphia/Elsevier, 2016, 168-170.

7. G. J. Romanes. Cunningham's manual of practical anatomy. $15^{\text {th }}$ ed. Oxford medica publication reprinted Vol 3 Head and Neck and Brain. 2011, 64-68.

8. Shepard T.H., Andersen H.J. and Andersen H. The human fetal thyroid. Its weight in relation to the body weight, crown-rump length, foot length and estimated gestational age. Anat. Rec 1964; 148, 123-128.

9. Jackson C.M. On the prenatal growth of the human body and the relative growth of the various organs and parts. Am. J. Anat 1909; 9, 119-166.

10. Harjeet A, Sahni D, Jit I and Aggarwal AK. Shape, measurements and weight of the thyroid gland in northwest Indians. Surg Radiol Anat 2004; 26:91-95.

11. Marshall CF. Variations in the form of the thyroid gland in man. J Anat Physiol 1895; 29:234-239.

12. Lokanadham $S$ and Devi SV. Gestational age related developmental anatomy and histogenesis of human fetal thyroid gland. World J Med Sci 2011; 6:173-177.

13. Devishankar K, Bhanu S, Susan PJ and Gajendra K. Agenesis of isthmus of thyroid gland with bilateral levator glandular thyroidea. Int J Anat Vari 2009; 2:29-30.
14. Cicekcibasi AE, Salbacak A, Seker M, Ziylan T, Tuncer I and Buyukmumcu M. Developmental variations and clinical importance of the fetal thyroid gland. Saudi Med J 2007; 28(4):524-528.

15. Bernardes LS, Ruano R, Sapienza AD, Maganha CA and Zugaib M. Nomograms of the thyroid measurements estimated by 2-dimensional sonography. J Clin Ultrasound 2008; 36(4):193-199.

16. Ranzini AC, Ananth CV, Smulian JC, Kung M, Limbachia A and Vintzileos AM. Ultrasonography of the fetal thyroid: nomograms based on biparietal diameter and gestational age. J Ultrasound Med 2001; 20(6):613-617.

17. Achiron R, Rotstein Z, Lipitz S, Karasik A and Seidman DS. The development of the foetal thyroid: in utero ultrasonographic measurements. Clin Endocrinol 1998; 48(3):259-264.

18. Moore $\mathrm{KL}$ and Dalley AF. Clinical oriented Anatomy. $3^{\text {rd }}$ ed. Lippincott Williums-Wilkins, 2006, 1083-1085.

19. Asim kumar Datta. Essentials of Human Embryology. $5^{\text {th }}$ ed. Current Book International, 2007, 127-129.

20. Braun EM, Windisch G, Wolf G, Hausleitner L and, Anderhuber F. The pyramidal lobe: clinical anatomy and its importance in thyroid surgery. Surg Radiol Anat 2007; 29(1):21-27

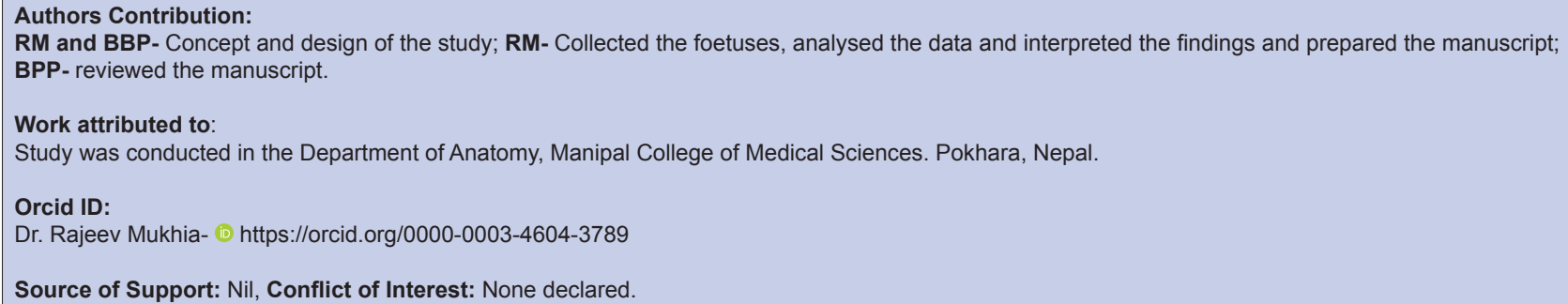

